\title{
'FITNA' IN EVERYDAY LIFE: Phenomena of the Digital Behavior of Indonesian Muslim Society on Dajjal Hadith
}

\author{
D.I. Ansusa Putra
}

Universitas Islam Negeri Sulthan Thaha Saifuddin Jambi, Indonesia

E-mail: ansusa@uinjambi.ac.id

\begin{abstract}
Dajjal appearance discussion in the last decade has been the trending among Muslim. There are massive search for religious doctrines text on Dajjal in digital media. This is oriented towards certain views about the world, social and cultural conditions, political project, political subjectivity, attitudes, and practice or competence. The behavior affects social-political life through the contextualization of hadith about Dajjal. This study aims to obtain a complete picture of digital media behavior in understanding religious doctrines related to Fitna of Dajjal among Muslims. This article combines Muslim theory of Cosmopolitanism Khairuddin Aljunied and living hadith approach, supported by data from google trend search throughout 2019. The results showed that there were four digital behaviors of Indonesian Muslim related to Dajjal hadith, first, searching instantaneously; second, reviewing from internet; third, joining the contextualisation discussion; and fourth, liking the personalization and illustration. The most frequently sought topic is about the prayer to be protected from Fitna of Dajjal. In addition, the study also tried to prove that this digital behavior is formed massively because of supply and demand pattern. It means that there are groups producing Dajjal hadith in public sphere regularly since they are supported by the many interests of consumers.
\end{abstract}

Ulul Albab Volume 21, No.1 Tahun 2020 
Satu dekade belakangan, bahasan kemunculan Dajjal telah menjadi tren di kalangan Muslim. Ada pencarian masif tentang teks doktrin keagamaan berupa hadis Dajjal di media digital. Ini berorientasi pada pandangan tertentu tentang dunia, kondisi sosial dan budaya, proyek politik, subjektivitas politik, sikap, dan praktik atau kompetensi. Perilaku tersebut berdampak pada kehidupan sosial-politik melalui kontekstualisasi hadis Dajjal. Penelitian ini ingin memperoleh gambaran utuh mengenai perilaku bermedia digital dalam memahami doktrin agama terkait fitnah Dajjal di kalangan muslim. Artikel ini mengkombinasikan teori muslim Cosmopolitanism Khairuddin Aljunied dengan pendekatan living hadis, didukung dengan data yang didapatkan dari google trend sepanjang 2019. Hasil penelitian ialah terdapat empat perilaku digital muslim Indonesia terkait hadis Dajjal, pertama, pencarian hadis dengan instan; kedua, menelaah di internet; ketiga, bergabung dengan diskusi kontekstualisasi; dan keempat, menyukai personalisasi dan ilustrasi. Adapun topik yang paling sering dicari adalah doa dijauhkan dari fitnah Dajjal. Selain itu, studi ini juga mencoba untuk membuktikan bahwa perilaku digital ini terbentuk secara massif karena adanya pola supply and demand. Artinya, terdapat kelompok yang memproduksi hadis Dajjal di ruang publik secara berkala karena didukung oleh banyaknya minat konsumen.

Keywords: Dajjal hadith; digital behavior; fitna of Dajjal

Received: November 16, 2019; Accepted: March 13, 2020

\section{Introduction}

In recent decades, the development of information technology has an impact on the development of mass media as a channel of communication through new media such as digital media and media convergences. New media or the so-called internet have a strong relationship with socio-cultural, economic and political fields. It is also closely related to Religion devices (Kurniawan 2012). All types of digital media is used by doctrinal texts (Putra and Chandra 2019). Indeed, at this time it is very easy to find the distribution of news related to religion. The media has become a very free public space to discuss various religions. The example is many online media uses Islam topic to gain public attention. At present, the media reaches an urgent position to achieve a variety of religious goals. 
The consistency of the correlation between new media and religion produces paradigms and new religious values. Furthermore, the media turns out to bring new theology in religion. Almost all communities are looking for sources of religious law or theological basis from new media (theology on new media) (Annazilli 2018). This condition is more factual with the appearance of internet.

This brings new values in religion for some people. Some people make use of this to learn about religion. In addition, it is also used as an intermediary in spreading religious content e.g. sharing the content of Quran and hadith using digital technology and social media intermediaries (Hidayaturrahman and Putra 2019).

The dissemination of religious content through digital media has been realized in its urgency by religious leaders personally as well as religious organizations or groups. This triggered religious organizations such as Nahdlatul Ulama, Muhammadiyah, Persis, and Majelis Ulama Indonesia to realize the importance of da'wah through digital media. New media (internet) has provided space for people/groups/institutions to spread religious values (Hidayaturrahman and Putra 2019). The religious organization declares mainstreaming al-Wasatiyah content using digital technology, such as websites, applications, and social media. This is because al-Wasatiyah content can be effectively distributed across space, time and even national boundaries (Hidayaturrahman and Putra 2019).

Therefore, it is no exaggeration to conclude that religion and the media have significant relations. On one hand, religion needs media as a tool to confirm its existence; on the other hand, media also consider religion as the subject of its development. Some researchers even mentioned that there are unique relationships between religion and media. At its development stage, the media has turned into religion for some people (Campbell 2012, 4). The new media not only functions as a cultureproducing etiquette, but also as a new religion/theology for some people. Therefore, academic discourse between religion and the media is always interesting to study in the science development.

The function of digital media in some cases has intervened the core domain of religion. For example, digital media has changed the pattern of understanding religious doctrines (Putra and Chandra 2019). One of them is the inclusion of Dajjal hadith in digital media logic. There is an understanding of Muslim eschatology coming from hadith information that has spread among Muslims. In the Mediatization of Islamic Doctrine in A New 
Era of Digital Indonesia: The Case of the Hadith on the Dajjal, I mentioned that Dajjal's hadith is categorized as predictive hadith i.e. hadith with character prediction of the future at qiyâmah (Judgement Day). Dajjal is informed in the hadith related to the state of Muslims at qiyâmah (Lifintseva, Isaev, and Shishkina 2015, 528).

This hadith is widely found in Islamic literature. There are at least hundreds of hadiths, containing qiyâmah, that are related to Dajjal. The term often mentioned in this doctrine is "fitna of Dajjal". In this case, the word has different meaning from fitna in Islamic law context. Fitna means chaos (fawdah) at qiyâmah or the end of time (akhîr al-zamân). Furthermore, fitna became the basic concept of great symbolic value for the early Muslim community which was preoccupied with questions about continuity and survival - fitna, or disintegration represented the failure to maintain the harmony of society (Fisher 1994, 231). At first, Dajjal hadith can only be found in the literature of Islamic scientific treasures. After the era of digital technology, it is visualized in the form of illustration and personalization of Dajjal. The videos quickly spread amid the masses.

There are several articles related to Dajjal and its contextualization, first, the paper Fitnah: The End of Life of the Term of Religion in the Last Political Protest discusses the doctrine of 'fitna' in Islam with political protests occurred in Arab world during the Arab Spring period. Regarding Arab leaders, they were not prepared for the manifestation of 'fitna' and did not expect the threat posed by the protesters. Elsewhere in the world, this article has the same vision in seeing the Islamic doctrine of 'fitna' and its contextualization in society (Lifintseva, Isaev, and Shishkina 2015). The difference is that this article does not include the political sphere. This article only looks at 'fitna of dajjal' in the daily lives of people that are spread very massively through the digital/internet world.

Second, the article entitled Dinamika Pemahaman Ulama tentang Hadis Dajjal (Dari Interpretasi Tekstual ke Interpretasi Kontekstual) intends to describe the figure of Dajjal mentioned in several traditions in Kutub alSittah (six primer hadith's books) and to explain how textual and contextual interpretations of the traditions speak of the past. Hadith information describes Dajjal as a fat reddish man, curly hair, one of his eyes is blind and his eyes are like ripe grapes (not radiant). Contextually, the scholars understand the characteristics in different ways. For example, the eyes are symbol/metaphor to explain control of what is happening today, and as a 
conspiracy to rule the world, and as a link to Western and Jewish culture that is deceitful, the wrong leader, and the thoughts that tend to be worldly (Armita and Arni 2017).

Third, my article entitled Mediatization of Islamic Doctrine in A New Era of Digital Indonesia: The Case of Hadith on the Dajjal, only focused on how the conversion of the Dajjal hadith from textual to illustration and visualization (Putra and Chandra 2019). In contrast, this article is a followup study that will examine the digital behavior of Indonesian people related to Dajjal hadith.

Digital behavior in this article shows the approach to behaviorism. Digital religious behavior itself is the response of religious communities in the face of digital technology. For Muslims, digital technology is seen as a positive thing, although they express it in different forms depending on the goals and orientation to be achieved (Campbell 2010, 13). This article looks at three discourses gathered in one point that influence one another: the Dajjal fitna hadith, digital behavior, and Muslim everyday life. Therefore, this article uses theories and approaches that can coordinate the three.

This paper uses the theory of cosmopolitanism Khairuddin alJunied. The theory sees the behavior of social media which is rooted in Islamic tenet in everyday phenomena and sees the virtual world as one of daily phenomena representing real Muslim life. This article then uses the living hadith approach. This approach starts from the community's behavior in the reception of hadith (context) and is certainly very helpful in expressing understanding about Dajjal hadith in digital society. The difference between conventional hadith studies and living hadith lies on the text and practice. If the ma'an al-hadith/fahm al-hadith rests more heavily on the text, then the study of living hadith is more focused on studying the practices that occur in society. Urgency of this study is to integrate hadith into social-political studies (Afwadzi 2016). Therefore, Muslim cosmopolitanism used to see digital dynamics as the most appropriate element to describe the daily behavior of Muslims. While the study of living hadith is needed to analyze the phenomena of practice, tradition, ritual, or behavior that lives in a society based on the Dajjal hadith.

\section{Dajjal in Hadith as the Biggest 'Fitna'}

Dajjal is a central figure in the end-time traditions as one of the ten signs of dooms day. The appearance of Dajjal is included in Qiyâmah Kubrâ (big signs). That is, the sign that appears close to qiyâmah and not the usual 
signs. Together with 10 other big signs, such as fog, Dajjal, Dâbbah (Beast), rising sun from the west, the fall of Prophet Isa, Ya $a^{\prime} j \hat{u} j$ and $M a^{k} j \hat{j} j$, landslides in the east, landslides in the west, landslides in the Arabian Peninsula, and fire Yemen (Muslim 2010, 2225). In some traditions, Dajjal is described as a great Fitna at the end of time, but he is also a symbol of the coming revelations. Therefore, people know how the characteristics of the end times (Armita and Arni 2017, 209), and know that the signs of his arrival is an important thing in Islamic doctrine.

In terms of traditions, the scholars agree that the fit of Dajjal is a great slander throughout the journey of the Children of Adam on this earth until the Judgment Day (Saritoprak 2003, 293). This is due to various forms of abilities possessed by Dajjal, as explained in many narrations. The two fitna that are actually carried by Dajjal to recruit followers are fitnah shahwat and fitnah shubuhat.

Dajjal has the power of witchcraft and deception that will greatly deceive many people and make them slandered into being loyal followers. A hadith reported by Muslim said:

"Abû Huraira reported Allah's Messenger (PBUH) having said: "Hasten to do good deeds before six things happen: the rising of the sun from the west, the smoke, the Dajjal, the beast and (the death) of one of you or the general turmoil” (Muslim 2010, vol. 4, 2267).

Because of the Prophet's worry from the existence of this greatest fitna Dajjal in the midst of his people, he always warns them of the danger and in many traditions he has explained sto them the matters related to Dajjal in detail (Armita and Arni 2017, 212). Because of the harmful effects of Dajjal's deception, all the Prophets warned his people from the defamation of Dajjal, as in the hadith reported by al-Bukhârî:

"From Anas said that the Prophet (PBUH) said: "Allah did not send any prophet but that he warned his nation of the one-eyed liar (al-Dajjâl). He is one-eyed while your Lord is not, the word 'Kaffir' (unbeliever) is written between his two eyes" (Khan 1985, vol. 4, 326).

Maybe many of us are still wondering, why Dajjal is the largest fitna in the world as mentioned in the previous hadith? The following points may answer: he has the highest level of sorcery in the world and is the ruler of all magicians. Among the magic he creates are: showing heaven to call on 
many followers and also showing hell to frighten those who have strong faith, reviving the dead he killed. Hadith says:

"The Dajjal kills someone and then revives him" (Muslim 2010, 2938).

Some scholars say that at first Dajjal will claim to be a Muslim, then a prophet and ultimately claim to be God (Fatkhullah, Nur, and Darsa $2018,41)$. He is also able to create rain and grow plants instantly with his magic. He can visit all places on this earth in a short time besides Mecca and Medina because both cities are guarded by Allah's angels. From Nawwâs ibn Sam'ân, The Messenger of Allah said:

"He came to people to preach them. They also believe in him, receive his da'wah. Then Dajjal commands the sky to rain and orders the earth to grow plants, then it rains and plants grow" (Muslim 2010, 2937).

In the authentic hadith form Tamîm al-Dârî, the Dajjal said:

"... then I will go out and surround the world. There is no area except me in 40 nights, except Makkah and Tayibah (another name for Medina) because they are forbidden to me. Every time I will enter one of them, I will be blocked by angels who in their hands are swords drawn to hold me away from both ..." (Muslim 2010, 2261).

\section{Combining Muslim Cosmopolitanism to Living Hadith}

The dimensions of religion in daily life are often escaped from the view of Islamic scholars, at least before the approach to living Quran and hadith in Islamic studies. This is because the daily life of religion is considered not an authoritative resource in Islam. Usually the daily life of religion is outside the frame and usually does not get approval from religious authorities. The shift in orientation of science also affects the development of Islamic studies from text to context. Then the development of contemporary humanism-based scholarship forced scholars to understand the emptiness of religious authoritative material with the religious behavior of people. Religious studies have been introduced and recognized as a form of religious understanding. The study of living hadith itself is a reception to the text of hadith done by a person or group manifested in the practices/rituals/traditions/behavior of the community (Qudsy 2016, 186).

Living hadith is a methodological tool in the practice of hadith. Each methodology requires an approach as a perspective used by researchers 
in conducting studies. Social research really requires an approach to be focus. The data analysis that adopts qualitative approach is generally inductive and deductive or a combination of both. Inductive is the process of drawing conclusions from a small case investigation in detail to get the big picture (reference). In other words, data in the form of fragments are arranged to produce a large picture that is inferred. Inductive processes enable the emergence of new theories in research. So, the research on living hadith requires an approach. There are several approaches in the study of living hadith, for instance, anthropology. phenomenology, narrative studies, and ethnography (Qudsy, 2016, 189-92).

This article uses an anthropological approach to religion. The term anthropology comes from the words anthropos and logos, which means humans and science. Anthropology is a term used in branches of science that talks about humans (Eller 2014, 4). In the Kamus Besar Bahasa Indonesia (KBBI), anthropology is referred to the science of man, specifically about the origin, the colorful colors of physical form, customs and beliefs of the past (Kementerian Pendidikan dan Budaya 2016, 147). From the descripstion above, it can be said that anthropology is a study of humans both in matters relating to physical aspects namely: skin color, hair shape, face shape, nose shape, height and in matters relating to social life.

The tradition that emerged from Eller's religious studies, had a twosided direction; first, a study of historical data on religion, and second, a tendency towards studying the structure or content of religious life itself. In its development phase, religious anthropology is divided into several streams, including functional flow, structural flow, and historical flow. Religious studies can be categorized in two ways: what is religion and what does religion do for other. The first thing is related to the meaning of religion for humans, while the second thing is related to the role or function of religion for humans. Through this categorization, what really becomes the target of religious research is religion that lives in human life (Eller 2014, 20).

One of the theories in religious anthropology is the theory of Muslim cosmopolitanism Khairuddin al-Junied that I employ in this article. This theory is considered relevant to see the digital behavior phenomena of Muslim societies related to Dajjal hadith. Khairuddin al-Junied made steps in the theory to see the daily life of Muslims. First, pay attention to daily behavior not at religious festivals; at the beginning of anthropology of religion studies, the media and Islamic scholars only took the attention of 
religious jubilation at festivals, ritual practices, and stories of the wonders of religion. This has received criticism from several Western scholars and Muslims themselves. Khairuddin al-Junied in Muslim Cosmopolitanism Southeast Asian Islam in Comparative Perspective states that it should not be enough to study the practice of Islam by looking at the phenomenon of Islamic festivalization, for instance, Balimau bath festival studies, Tabot studies, Safar bath festivals, Ramadan, Eid al-Fitr, etc. The entire festival does not comprehensively describe the true content of the Islamic community (AlJunied 2016, 26). So Khairuddin al-Juneid said it was necessary to study the Muslim community through its daily behavior. Daily behavior can be seen in certain places and spaces. Such as: markets, mosques, and virtual worlds. All three represent real Muslim practices and behavior as Islam they understand and practice.

The Cosmopolitan Muslim theory Aljunied outlines three Muslim marvelous behaviors that emerge in the virtual world; first, intensity, second, contextualization, and third, following global discussion. All three form behaviors interconnect to one another (AlJunied 2016, 32). AlJunied offers the concept of Muslim cosmopolitanism to see the daily behavior of Muslim societies which originate from these three places and spaces. Cosmopolitan Muslim itself is a form of thinking in seeing the world and way of life which is rooted in the main principles of Islam. The principles state that every human being is part of global humanity that is accountable to God and every human being morally responsible for others.

Being a cosmopolitan Muslim means showing a high level of acceptance of the universal values that are embedded in their own customs and traditions (adat). Muslim cosmopolitanism allows one to be lightened with Islam and one's own cultural identity, promoting this identity as a means to enrich public understanding of Islam and Muslims while maintaining and embracing tolerant attitudes towards people from diffeerent backgrounds.

Furthermore, Cosmopolitan Muslims are oriented towards cosmopolitan civilization values, crossing cultural barriers, and fighting for the upholding of public civilization. Aljunied said that one of the concrete proofs of Muslim cosmopolitanism in Southeast Asia is the existence of Muslim blog, which is a virtual Muslim world used to describe their daily lives. The blog was formed with cosmopolitan Muslim values (AlJunied 2016). 


\section{Everyday Life of Dajjal Hadith}

Applying religious doctrine in daily behavior is essential for Muslims. Muslims understand that all religious doctrines must be practiced in daily life, especially those contained in the Quran and hadith. This background causes many Muslim-majority countries to practice religious norms in daily life, because Muslims realize that the Quran and hadith function as guides of human life in their lives to achieve happiness in the hereafter. According to the survey, it is stated that the awareness of Muslims in practicing their religious doctrines is quite high, such as: Jordan (84\%), Kuwait (78\%), Saudi Arabia (76\%), Pakistan (72\%), Morocco (67\%), Lebanon (60\%), and Indonesia (53\%). Only Turkey (41\%) has a lower yield than the number of respondents in offering religion as an essential value in their lives (Poll 2016).

One of the religious lessons that is accountable in Muslim daily life is the belief about the End of Times (qiyâmah) and everything related to it. Hadith mentioning qiyâmah becomes the reference of Muslim's everyday life (Putra and Chandra 2019, 176). Some terms related to qiyâmah are very well-known among Muslim, such as: Fitnah, Dajjal, Imam Mahdi. Even in their prayer, a Muslim is encouraged to pray free from the defamation of the Dajjal (Khan 1985, vol. 4, 326).

"It was from Urwah that Aisha said I heard the Rasulullah take cover in her prayers from the Fitna of Dajjal."

This indicates how close this doctrine is in the daily lives of Muslim societies. Hadith even informs you in detail about the Dajjal's fitna. Dajjal is described as a human being who is blind (Armita and Arni 2017). The Dajjal's fitna will occur at the end of the age which has tremendous power to humans. It will affect the whole world with his expertise except Mecca and Medina (Khan 1985, vol. 2, 25 and 325). However, the behavior that is too quick to match reality with hadith without in-depth study is not justified; moreover, it is also not right to claim that what contains in hadith is a certain reality.

This trust is followed up by the Muslim community in their daily lives which are already based on the internet and social media. Therefore Muslims do digital behavior related to it even with different goals. Through the theory of Muslim cosmopolitanism, it is known that discourse related to the theme of Dajjal fitna in the virtual world can be categorized as the daily life of Muslims in accepting and understanding the universal doctrine. The 
difference in the purpose of religious behavior in Muslim societies when knowing about Dajjal hadith on social media can be evidenced by the massive media that serves Dajjal and end-time content. Some of them are content providers (producers) and most Indonesian Muslims are only recipients (consumers) of content about Dajjal.

From data collection it is known that the trend of searching for the Dajjal hadith in Indonesia's digital behavior has increased since 2018-2019. Even in November 2018 (week 39) there was an increase in search trend about Dajjal that is $98 \%$ of all internet topics throughout Indonesia. This shows that the doctrine of Dajjal is a religious belief that has become a daily digital behavior of Indonesian Muslim community. Searches on Dajjal topic are evenly distributed throughout Indonesia in 2019. The 10 highest searches in Indonesia are: Aceh (100), Central Sulawesi (91), Bangka Belitung Islands (85), South Sumatra (80), Southeast Sulawesi (80), Lampung (80), West Sulawesi (79), Riau (78), West Nusa Tenggara (76), and Jambi (76).

Therefore, it can be concluded that the material about Dajjal hadith is very close to the daily lives of Indonesian Muslims. In fact, the topic of Dajjal is related to the social and political dynamics of society. Political events are very easily related to the existence of Dajjal in Islamic religious doctrine. For example, the debate about the mosque architecture in Bandung rest area which is allegedly similar to Dajjal hadith contents triggered people to accuse the Governor of West Java, Ridwan Kamil, as a follower of Dajjal by Rahmat Baequni, a religious preacher who often includes the topic of Dajjal in his da'wah.

Picture 1

Dajjal Topic Search Trends 2019

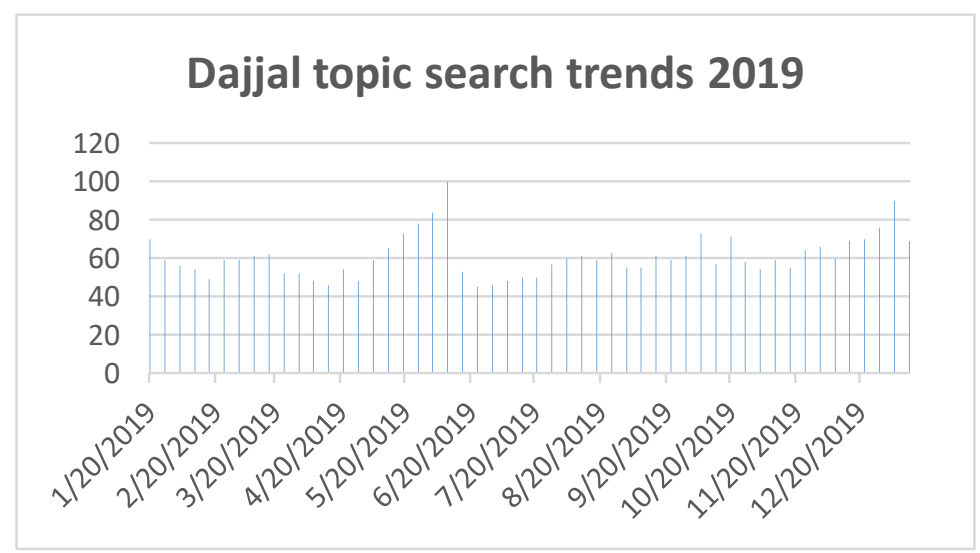

Ulul Albab Volume 21, No.1 Tahun 2020 
The association of the doctrine of Dajjal in Muslim life is also connected with the unique and strange natural cases e.g. the extreme drought in 2019 was claimed as a sign of Dajjal arrival (Ningtyas 2019). Indonesian Muslims even base their life choices with the belief in the doctrine of Dajjal, such as linking the President and Vice President of Indonesia General Election in 2019 with the battle of the end of time and the emerging of many more group and individual behaviors that originate from the religious doctrine. Those communities have widened religious doctrine to social political and even individual behavior. This makes some Western scholars conclude that there is a relationship between the belief (doctrine) of Dajjal and political upheaval in Muslim countries. For example, the article entitled Defamation: The Afterlife of a Religious Term in Recent Political Protest states that there is a link between the doctrine of 'fitna' with the chaos that occurs in the Arab world or popularly called 'Arab Spring' (Lifintseva, Isaev, and Shishkina 2015, 530).

The doctrine of Dajjal is also believed by Indonesian Muslims, and one of behaviors that arises related to it is the digital behavior of Indonesian people who incorporate the content of Dajjal doctrine in digital media. Digital behavior is the use of internet that has an impact on the way of human views related to religious traditions or doctrines (McClure 2017, 25). McClure also says that religious behavior in the digital era increased based on Wave III of the Baylor Religion Survey (2010). At the same time, he argues that the internet has made fundamentally different behavior from previous technologies such as television as well as providing a change in impact on religious beliefs and ownership associated with religious activities (McClure 2017, 21).

There are some digital behaviors of Indonesian Muslim societies related to the doctrine of Dajjal fitna. First, they search for Dajjal hadith instantly, because one of the characteristics of digital behavior today is to always choose the instant path. Nowadays, the internet becomes an inseparable part of humans. The digital age is not digitalization of media content, but the dynamic life of "new media" content and interactive relationships with media consumers themselves as described by Lev Monovich. It lies in the real time access (anytime easily). So, new media is a term intended to cover the emergence of digital, computer, or information and communication technology networks in the late 20th century (Aji 2016, 44). This ease is certainly very far from the study of hadith reality in ancient times when everything was still conventional i.e. searching through a book 
of hadith (Suryadilaga 2014, 203) or directly getting it from the person who narrated the hadith (Suryadilaga 2014, 204). However now, the development of information technology makes it easier for people to search for hadith through virtual spaces, such as internet browser, hadith applications, digital hadith libraries, digital hadith encyclopedias, etc. Even hadiths can be found in the writings of virtual communities, blogs, websites, and so on.

Picture 2

Topic Searching of Dajjal by Region

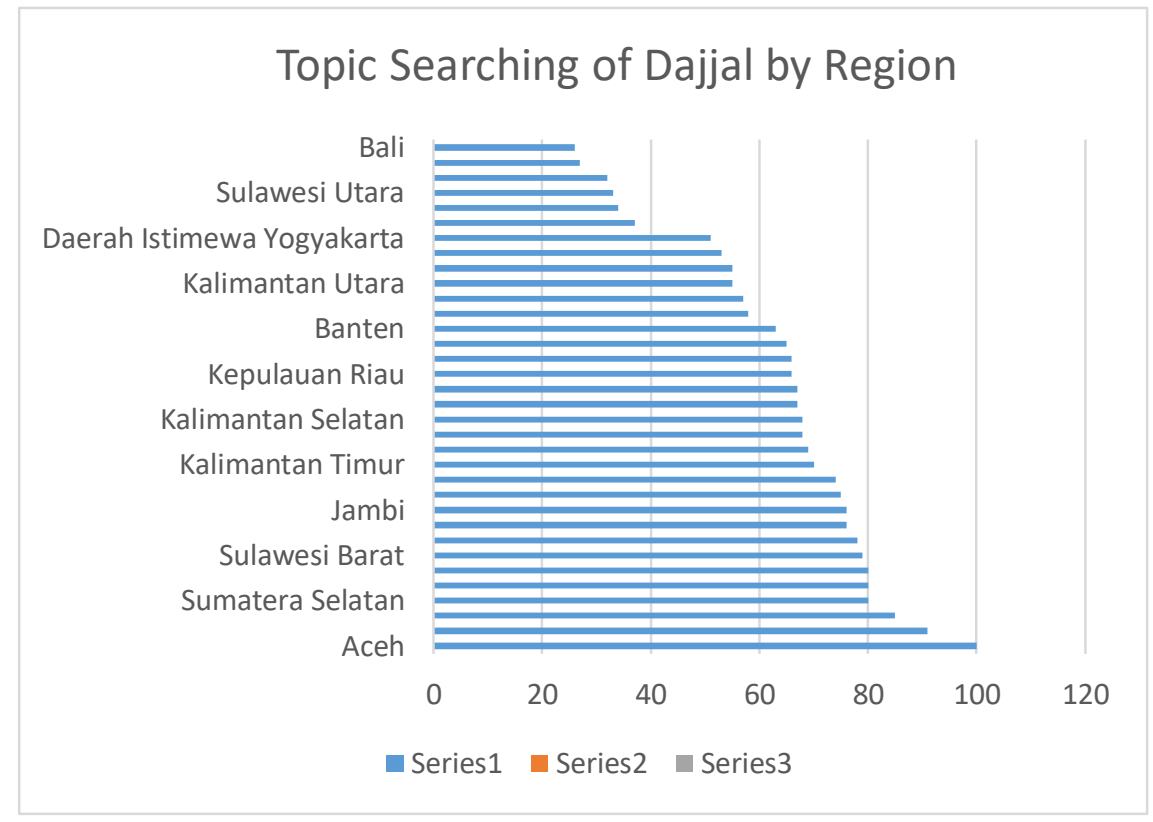

This change will certainly also affect the behavior of Muslim communities in searching for and accessing the Dajjal hadith. As a doctrine that lives in the life of Muslim societies, Dajjal hadith is certainly often accessed by Muslim communities especially in Indonesia. This can be proven by data from Google Trend which states that the search for the Dajjal hadith reaches a significant level. The increase in the search is also caused by the socio-political dynamics of Indonesian Muslims, so that some people look for spiritual justification in seeing phenomena that occur in society. This justification is usually a way of matching information between hadith and the reality prevailing around it. Religious doctrines are often politicized to get the attention and support of the wider community 
(Supriyadi 2015, 399). Especially Islam, this is because the religion has the most population in Indonesia, so it is not surprising that Islam is ridden with temporal social-political interests.

This can be seen from the frequency of religious doctrines that are often discussed rather than other SARA components with the birth of the term "politicization of religion". Especially in areas that are considered religious, the role of religion can be an interesting issue to study. Clifford Geertz himself found an authentic definition of religion because he conducted research in Java. According to him, religion is interpreted as a symbol that plays a role in building a strong, pervasive and long-lasting atmosphere in humans by formulating general conceptions of the life order and by tapping the conceptions with facts (Pals 2019, 262). This can be proven by the number of Dajjal topic access by region, where Aceh as the largest Muslim population area is also the highest Dajjal hadith search access. On the contrary, Bali as the lowest Muslim population area has the lowest access number of Dajjal hadith.

Second, reviewing the Dajjal hadith on the internet, Muslims not only tend to explore the Dajjal hadith on the internet, but also review the information. It is proven that the majority of millennial generation accesses the internet to access social media, including Facebook, Twitter, and WhatsApp. Muslim digital behavior related to Dajjal hadith is not only about searching for the matters related to it, but also reviewing the information from different virtual sources. This tendency is caused by Muslim community efforts to find valid and accurate information and its contextualization in daily life. Most of them are about questions and reviews on Dajjal hadith, such as the definition of Dajjal, the prayer, the fitna, the form, the picture, the follower, and its characteristics. The review is usually also compared with other related hadiths so that Muslim community has its own conclusion related to social phenomena. For example, Dajjal hadiths are reviewed with the hadiths of Imam Mahdi, famine, and smoke/fog (al-Dukhân) (Muslim 2010, vol. 4, 2155). 
Picture 3

Dajjal Search Query

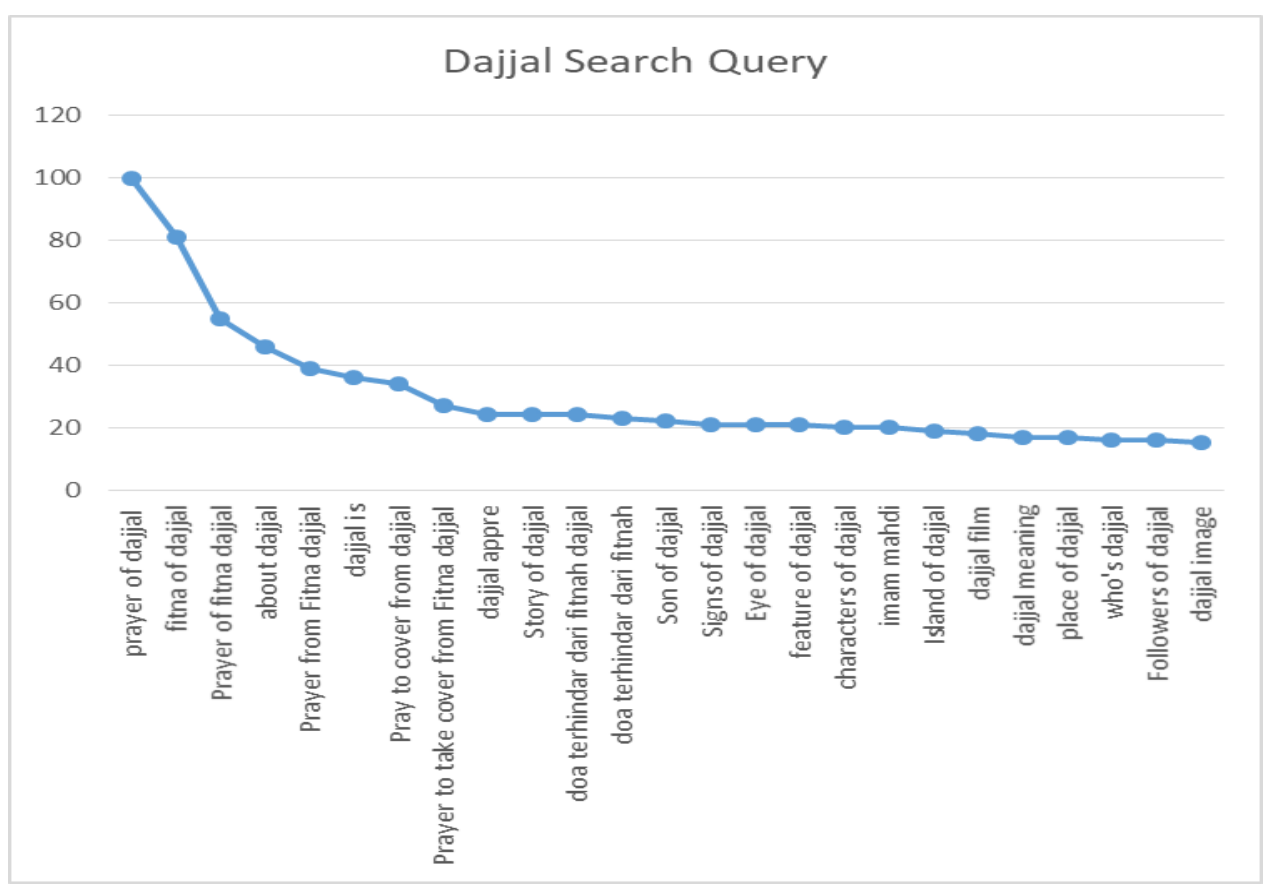

The third typical digital behavior of Indonesian Muslim is joining the discussion on Dajjal hadith. Internet has become a super medium of communication that makes every inhabitant can be interconnected everywhere all around the world. It also allows us to share and get information in just minutes or even seconds. Through the internet, the barriers of distance and time start to fade along with the increasing growth of its users. Furthermore, the millennial generation, better known as internet generation, was also born along with the development of internet (Imron 2019). They are indeed superior in the use of technology including the internet compared to previous generation (Deal, Altman, and Rogelberg 2010). One of characteristics of millennial generation is "connected" which can be interpreted that millennial generation is the generation that actively uses the internet and social media (Ali and Purwadi 2016). The ease of access makes the public also joins in public discussion in digital media about Dajjal hadith and its contextualization in the topic of social and political dynamics in Indonesia. This can be seen from the debate about architecture of the mosque in Bandung which is accused of resembling the 
Illuminati building. Illumniti itself is a world secret organization that is often associated with Dajjal.

Picture 4

The Rising Topics Related to The Dajjal Hadith

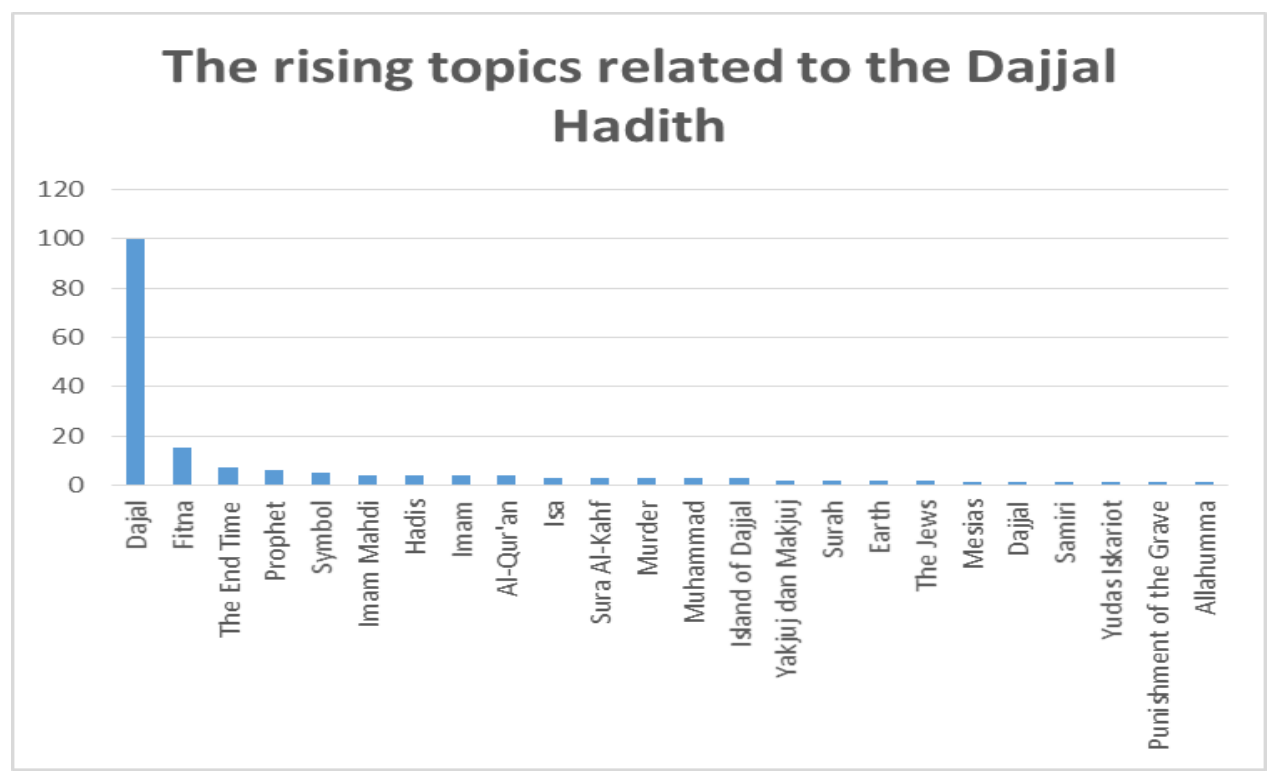

The fourth behavior is that Muslim society likes the personalization and illustration of Dajjal. With the availability of the internet, all necessary information are presented in one tap. In YouTube platform, there are more than 200 of Dajjal-related short videos which have been watched million times. They personalize and illustrate Dajjal, explain the history of his life, and the strength he has (Putra and Chandra 2019, 192). The Dajjal's personalization and illustration received attention (likes) from Indonesian Muslims. This illustration usually refers to the explanation on a figure who often campaigns for Dajjal, such as Rahmat Baequni and Zulkifli Ali. These two figures have become references in beliefs about Dajjal hadith in Indonesia. This is proven by the number of uploaded videos in Youtube that contain the explanation from both figures.

This personalization and illustration display the Prophet's hadiths related to the theme, without mentioning the source of the reference in detail. Video makers only include narrators without mentioning the book and the volume of the hadith. In addition, the video also does not include 
an analysis of the hadiths quality both physically and historically. The analysis of hadith in a riwâyah is one of requirements in disseminating hadith to public (Purwaningsih 2017, 280) so that people are not misled and can understand how the contextualization of it in daily life.

Picture 5

YouTube Video Related to Dajjal
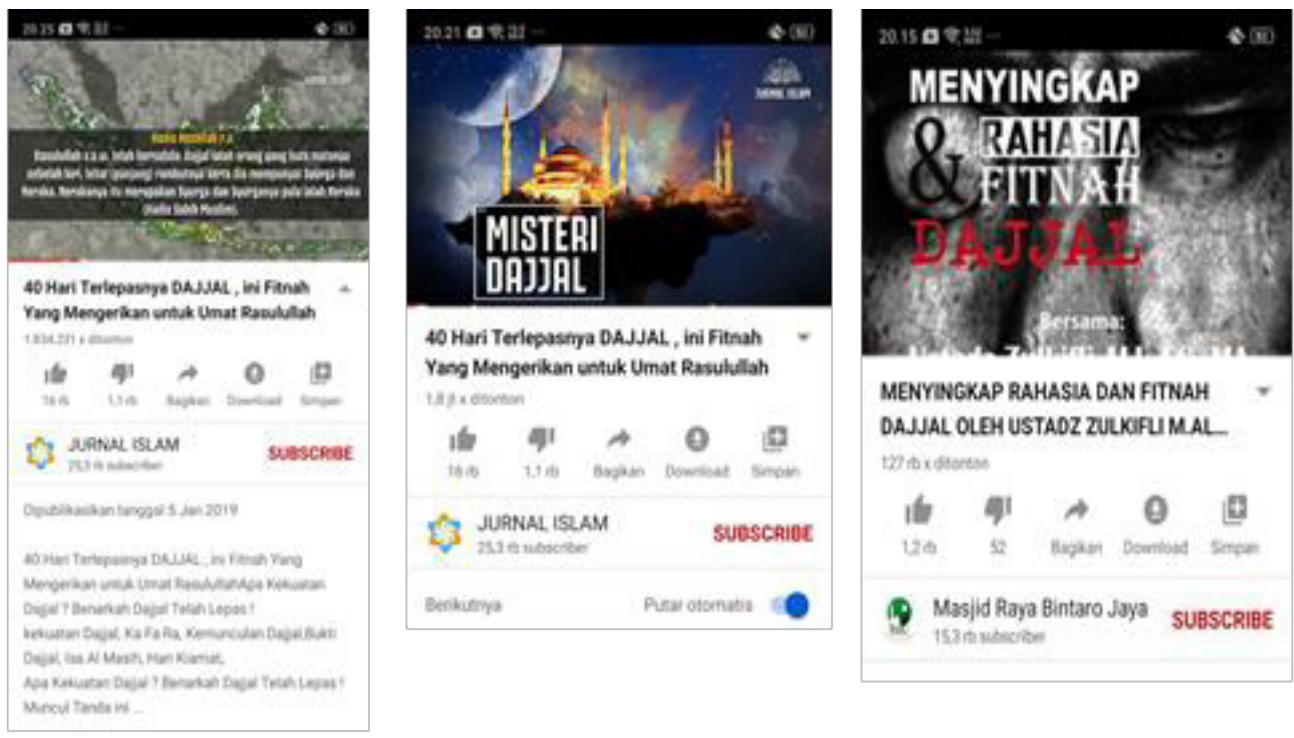

MENYNGKAP RAHASUA DAN FITNAH

DAJJAL OLEM USTADZZ ZULKIPUMAL 127 is xederes

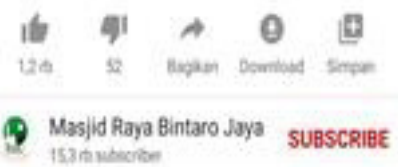

Topics of Dajjal Hadith on Indonesian Muslims' Digital Behavior

Fitna Dajjal seems to really affect the lives of Indonesian Muslims. This can be seen from the topics that are often sought after by the Muslim community in digital media. Prayers avoiding the defamation of the Dajjal are the topics most frequently sought and searched by them. It also refers to the hadith of the prophet who encouraged Muslims to recite prayers to avoid the defamation of the Dajjal after each prayer.

Dajjal fitna in this context is interpreted as lies issued by Dajjal so that humans are fascinated and can no longer distinguish between right and wrong. It is one of abilities of Dajjal to make people believe in his lies. One of the ways to lift up Dajjal's fitna is to read surah al-Kahf according to Prophetic hadith. The hadith warning people to keep away from fitna also hints Muslims to always be aware of Dajjal's appearance that can come anytime. 
Picture 6

Discussion about Dajjal

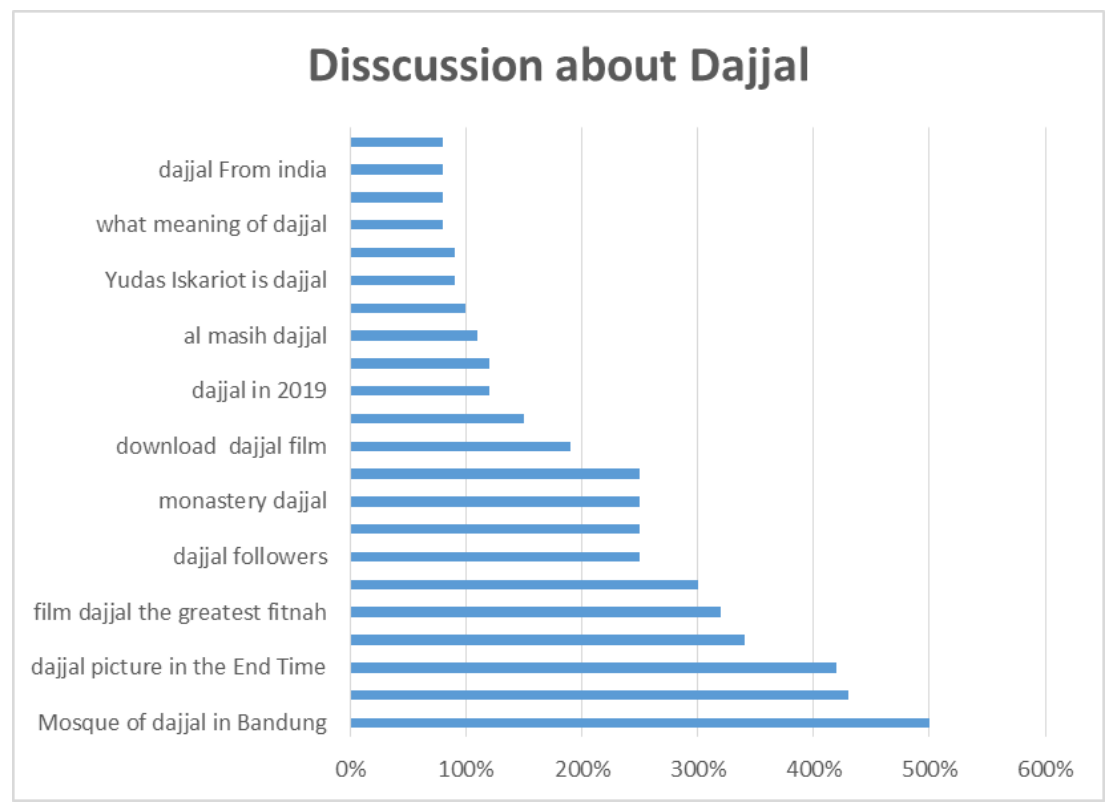

The topic that is often searched is Dajjal's characteristics which is from the Prophetic hadiths. These hadiths are taken from authoritative books i.e. al-Bukhârî and Muslim. In the hadith, Dajjal is described as beings looking like human with special characteristics e.g. the one-eyed Dajjal since his another eye is blind. This is what might cause the suspiciousness of illumination phenomena where one-eye is the symbol. The symbols are scattered throughout the realm of modern human life e.g. money, building, monuments, road design, and company symbols. Even, a mosque architecture is accused as a product of illumination i.e. as-Safar Mosque in Bandung which triggers harsh comments among Indonesian citizen (Pojoksatu 2019).

The Dajjal is also characterized by the Prophet. On the forehead between his eyes there is an inscription - kaf fa ra - which means infidel and it can only be read by believers even if the person is illiterate. Originally, Islamic community did not know enough about the characteristics of Dajjal from the Prophetic hadiths. However, they then try finding the information through the internet. Therefore, the image of the Dajjal becomes the most sought after topic. This resulted in the emergence of Dajjal illustrations and personalization in the virtual world. 


\section{Producer and Consumer of Dajjal Hadith in Indonesian Media}

All new media have the same characteristics, which are related to distribution, production and consumption. Its characteristics are digital, interactive, hypertextual, virtual, networked, and simulative. Without technical elaboration, these characteristics enable new media to present various forms of content, such as text, video images, and sound, all together as part of the same media, based on digital technology (Dahlan 2012). It also transforms new media audiences into independent autonomous users who are free to choose specific content or topics, in the form of presentations, from any on internet. The users feel more comfortable because of interactive, hypertextual, and network of new media (Jinan 2012, 187).

The massive search on Dajjal hadith of Indonesian Muslims is inseparable from the existence of economic needs. The pattern of supply and demand applies, specifically related to short videos and illustrations of Dajjal hadith on YouTube channel. The magnitude of Muslim's curiosity on everything related to Dajjal, plus the mainstreaming of Dajjal hadith in public spaces make the public enthusiastic to witness the personalization of Dajjal's fitna. This makes some organized accounts to upload illustrations regularly. No less than 30 accounts have distributed the latest material on illustrations of Dajjal fitna and those related to it. However, there are five accounts that are classified as producers of Dajjal defamation video, namely UZMA TV Channel, Kabakhirzaman, Yufid TV, Islamic Journal, and Islamic Encyclopedia.

Youtube is not only information but also economic oriented. This is due to the economic benefits obtained when a video is watched by many people (viewers). This adds motivation for digital Muslim behavior today, although digital behavior and the illustration of Dajjal on Youtube are not directly correlated.

However, internet surely has positive benefits besides its negative implications, depending on how people use it. In Indonesia, 83.23 percent of millennial generation claims they access internet for social media, 68.01 percent uses it to get information/news, meanwhile 46.81 percent uses it for entertainment. 


\section{Conclusion}

The existence of Islamic doctrine about Dajjal fitna is manifested by the Indonesian Muslim community in their digital behavior. Digital behavior is inseparable from three interrelated keywords: first, Dajjal Defamation; second, Development of Digital Media; and thirdly, Muslim daily behavior. Cosmopolitan Muslim theory Aljunied outlines three Muslim marvelous behaviors emerging in the virtual world: first, intensity; second, contextualization; and third, following global discussion. All three form behaviors are interconnected to one another. The digital behavior can be concluded in three main behaviors: 1) searching Dajjal-related content easily and instantly, 2) reviewing Dajjal hadith on internet, 3) joining the contextualization discussion on Dajjal hadith, 4) liking personalization and hadith illustrations. Moreover the most searched topics in this context are the prayer to be protected from Dajjal fitna, Dajjal's appearance, characteristics, and image.

The aforementioned digital behavior of Indonesian Muslims related to Dajjal fitna can be categorized both in positive and negative sides because social media on one hand provides useful information. On the other hand, it can cause chaos and prejudice if it is not understood properly and correctly. Therefore, digital behavior depends on the orientation and purpose of the media user in this case Muslim community. Digital behavior as mentioned also must get good guidance from community leaders so that the Muslim can comprehend the content correctly.

\section{References}

Afwadzi, Benny. 2016. "Membangun Integrasi Ilmu-Ilmu Sosial Dan Hadis Nabi." Jurnal Living Hadis 1(1): 101-27.

DOI: https://doi.org/10.14421/livinghadis.2016.1070

Aji, Rustam. 2016. "Digitalisasi, Era Tantangan Media (Analisis Kritis Kesiapan Fakultas Dakwah Dan Komunikasi Menyongsong Era Digital)." Islamic Communication Journal 1(1): 43-54.

DOI: http://dx.doi.org/10.21580/icj.2016.1.1.1245

Ali, Hasanuddin, and Lilik Purwadi. 2016. Indonesia 2020: The Urban Middle Class Millenials. Jakarta: Alvara Research Center.

AlJunied, Khairuddin. 2016. Muslim Cosmopolitanism Southeast Asian Islam in 
Comparative Perspective. Edinburg: Edinburg University Press.

Annazilli, Haqqi. 2018. "Relasi Antara Agama Dan Media Baru." Jurnal Ilmiah Syi'ar 18(2): 26-44.

DOI: http://dx.doi.org/10.29300/syr.v18i2.1677

Armita, Pipin, and Jani Arni. 2017. "Dinamika Pemahaman Ulama Tentang Hadis Dajjal (Dari Interpretasi Tekstual Ke Interpretasi Kontekstual)." Jurnal Ushuluddin 25(2): 208c20.

DOI: http://dx.doi.org/10.24014/jush.v25i2.2398

Campbell, Heidi A. 2010. When Religion Meets New Media. London and New York: Rouledge.

Campbell, Heidi A. 2012. Digital Religion: Understanding Religious Practice in New Media Worlds. London and New York: Rouledge.

Dahlan, Alwi. 2012. "Understanding the New Media." Suara Merdeka.

Deal, Jennifer J., David G. Altman, and Steven G. Rogelberg. 2010. "Millennials at Work: What We Know and What We Need to Do (If Anything)." Journal of Business and Psychology 25(2): 191-99.

DOI: https://doi.org/10.1007/s10869-010-9177-2

Eller, Jack David. 2014. Introducing Anthropology of Religion. London and New York: Rouledge.

Fatkhullah, Faiz Karim, Tajudin Nur, and Undang Ahmad Darsa. 2018. "The Reception of Dajal Story in The Saifu Ad-Dharib." Humanus 17(1): 37-52.

DOI: https://doi.org/10.24036/humanus.v17i1.8779

Fisher, Humphrey J., and Virginia Rowland. 1971. "Firearms in the Central Sudan." The Journal of African History 12(2): 215-39.

DOI: https://doi.org/10.1017/S0021853700010641

Hidayaturrahman, Mohammad, and D.I. Ansusa Putra. 2019. "The Role of Technology and Social Media in Spreading the Qur'an and Hadiths by Mubalig." Dinika: Academic Journal of Islamic Studies 4(1): 45-64. DOI: $10.22515 /$ dinika.v4i1.1858

Imron, Ali. 2019. "The Millenial Generation, Hadith Memes, and Identity Politics: The New Face of Political Contestation in Contemporary Indonesia." Ulul Albab: Jurnal Studi Islam 20(2): 255-83. 
DOI: http://dx.doi.org/10.18860/ua.v20i2.5675

Jinan, Mutohharun. 2012. "New Media Dan Pergeseran Otoritas Keagamaan Islam Di Indonesia." Jurnal Lektur Keagamaan 10(1): 181-208.

DOI: http://dx.doi.org/10.31291/jlk.v10i1.178

Kementerian Pendidikan dan Budaya. 2016. Kamus Besar Bahasa Indonesia $(\mathrm{KBBI})$.

Khan, Muhammad Muhsin. 1985. Sahîh Al-Bukhârî (Summarize). Darussalam.

Kurniawan, Fachrul. 2012. "Pemanfaatan Langsung Teknologi Informasi Dalam Dakwah Islam." Ulul Albab: Jurnal Studi Islam 13(1): 65-76. DOI: http://dx.doi.org/10.18860/ua.v0i0.2379

Lifintseva, Tatyana P., Leonid M. Isaev, and Alisa R. Shishkina. 2015. "Fitnah: The Afterlife of a Religious Term in Recent Political Protest." Religions 6(2): 527-42.

DOI: https://doi.org/10.3390/rel6020527

McClure, Paul K. 2017. "Tinkering with Technology and Religion in the Digital Age: The Effects of Internet Use on Religious Belief, Behavior, and Belonging." Journal for the Scientific Study of Religion 56(3): 481-97.

DOI: https://doi.org/10.1111/jssr.12365

Muslim, Imâm. 2010. Sahịh Muslim. Beirut: Dâr al-Fikr.

Ningtyas, Ika. 2019. "[Fakta Atau Hoaks] Benarkah Ada Kemarau Panjang Dalam 3 Tahun Dan Menjadi Tanda-Tanda Kedatangan Dajjal?" https://cekfakta.tempo.co/fakta/361/fakta-atau-hoaks-benarkahada-kemarau-panjang-dalam-3-tahun-dan-menjadi-tanda-tandakedatangan-dajjal (January 5, 2020).

Pals, Daniel L. 2019. Eight Theories of Religion. Oxford: Oxford University Press.

Pojoksatu. 2019. "Masjid Al Safar Disebut Simbol Dajjal, Ridwan Kamil: Merusak Nama Baik Dan Keimanan Saya." https://pojoksatu.id/news/berita-nasional/2019/06/01/masjid-alsafar-disebut-simbol-dajjal-ridwan-kamil-merusak-nama-baik-dan- 
keimanan-saya/ (January 5, 2020).

Poll, Gallup. 2016. "Religion Dominates Daily Life in the Islamic World." https://news.gallup.com/poll/5383/religion-dominates-daily-lifeislamic-world.aspx (January 5, 2020).

Purwaningsih, Sri. 2017. "Kritik Terhadap Rekonstruksi Metode Pemahaman Hadis Muhammad Al-Ghazali." Jurnal Theologia 28(1): 75-102.

DOI: http://dx.doi.org/10.21580/teo.2017.28.1.1189

Putra, D.I. Ansusa, and Agus Firdaus Chandra. 2019. "Mediatization of Islamic Doctrine in A New Era of Digital Indonesia: The Case of Hadits on Dajjal." Jurnal Theologia 30(2).

DOI: http://dx.doi.org/10.21580/teo.2019.30.2.4327

Qudsy, Saifuddin Zuhri. 2016. "Living Hadis: Genealogi, Teori, Dan Aplikasi." Jurnal Living Hadis 1(1): 177-96.

DOI: https://doi.org/10.14421/livinghadis.2016.1073

Saritoprak, Zeki. 2003. "The Legend of Al-Dajjāl (Antichrist): The

Personification of Evil in the Islamic Tradition." Muslim World 93(2): 291-307.

DOI: https://doi.org/10.1111/1478-1913.00024

Supriyadi, Mohammad. 2015. "Politisasi Agama Di Ruang Publik: Komunikasi SARA Dalam Perdebatan Rational Choice Theory.” Jurnal Keamanan Nasional 1(2): 387-428.

DOI: https://doi.org/10.31599/jkn.v1i3.32

Suryadilaga, Muhammad Alfatih. 2014. "Kajian Hadis Di Era Global." Esensia: Jurnal Ilmu-Ilmu Ushuluddin 15(2): 199-212.

DOI: https://doi.org/10.14421/esensia.v15i2.773 